\title{
Bangladeshi Honey: A Possible source of beneficial Aerobic Bacteria
}

\author{
Md. Abir Hossain ${ }^{1}$, Sarbojoy Saha ${ }^{1}$, Abhinandan Chowdhury ${ }^{1 *}$
}

\author{
${ }^{1}$ Department of Biochemistry and Microbiology, North South University, \\ Plot\#15, Block\#B, Bashundhara, Dhaka 1229, Bangladesh. \\ *Corresponding Author: Abhinandan Chowdhury, North South University, Plot\#15, Block\#B, Bashundhara, Dhaka 1229, \\ Bangladesh. \\ E-mail: abhinandan.chowdhury@ northsouth.edu
}

\begin{abstract}
Honey is known to have many health benefits and hence had been used as natural medicine for ages. Literature suggests that bioactive agents can come from the secondary metabolites produced by the bacteria present in honey. Existence of several bacteria has been reported in European and Australian honeys. Therefore, the aim of this study was to isolate and identify the bacteria present in honeys available in Bangladesh. Honey samples from seven types of natural flowers and six commercial kinds of honey of Bangladesh were tested in this study. Prevalence of bacteria in each sample was checked through serial dilution method. Then different types of bacteria were identified by culturing them on selective agars and biochemical tests. Presence of Micrococcus luteus(100\%), Streptococcus (92\%), Staphylococcus aureus(77\%), Bacillus (23\%), Lactobacillus (15\%), Klebsiella (8\%) and Escherichia coli $(8 \%)$ were detected.The secondary metabolites of these bacteria can be extracted and checked for potential development as medicines from nature
\end{abstract}

Keywords- Honey, Bacteria, Natural Products, Bangladesh.

\section{INTRODUCTION}

Honey is a natural sweetening agent that has been used as a sweetener in place of sugar for centuries. Apart from this, antibacterial agents, vitamins and antioxidants were reported to be present in honey. Therefore it is known to have numerous health benefits and is often used to treatcolds, cough, sore throats, dysentery, and many other infections[1]. Most bacteria and other microbes cannot grow or reproduce in honey due to the antibacterial activity of honey. It has been reported that Manuka honey has exhibited antimicrobial activity against a few pathogenic bacteria such as Helicobacter Pylori (H. Pylori).This is due to the secondary metabolites found in it and thus this honey can be used for the treatment of wounds and stomach
ulcers[2-4].Honey also inhibits the growth of quorum sensing bacteria [2]. The bees produce an enzyme (invertase) for processing honey inside their body. Honey is too concentrated for microorganisms to grow[5].In our previous research, we have shown that multidrug-resistant bacteria were found to be sensitive against Bangladeshi raw and commercial honeys. Also, the sensitivity of bacteria to antibiotic increases when honey is used alongside the antibiotics [6].

However, honey contains several microorganisms. Microorganisms which survive in honey are those that withstand the concentrated sugar, acidity and other antimicrobial characters of honey. Diluted honey inhibits the growth of pathogenic bacteria whereas they support the growth of non-pathogenic bacteria that can be useful for human health [7]. It has been observed that Bacillus, Micrococcus and Saccharomyces species could be readily isolated from honeycombs and adult bees [8]. Aerobic spore-forming Bacillusis the most frequently encountered microbes on the external surface and intestine of the honey bees [9-12]. A number of microbial species that have been isolated from the feces of bee larvae are Enterobacteriaceae, Penicillium spp., Aspergillus spp., and Torulopsis spp.[13]. These bacteria produce various antibiotics, other antimicrobial agents and secondary metabolites which can be beneficial to human.

Therefore, the aim of this study was to identify the bacteria in the raw and commercial honeys available in Bangladesh. And shed some light on the bioactive products that they can produce. 


\section{II. \\ METHODOLOGY}

Honey were collected from various sources.

From each source of honey, one sample was taken.

From each sample, number of CFU was determined by serial dilution method.

After that each sample was sub-cultured on selective culture media for identifiction of bacteria.

From selective media the colonies were subject to biochemical test for identification of bacteria.

\section{Results}

Fig.1: Workflow of the research.

Seven raw honey samples were collected from different locations of Bangladesh, and six commercial honey $(\mathrm{C} 1-$ C6) samples were taken. For each sample, serial dilutions were prepared. An aliquot of $0.1 \mathrm{ml}$ from each dilution was transferred on to nutrient agar (HiMedia ${ }^{\circledR}$, M001) and cultured through spread plate technique. After incubation on the next day colonies were counted on each plate, and thus the number of CFU (Colony Forming Unit) was determined for all the honey samples. Then from nutrient agar, the colonies were subcultured on Mannitol Salt Agar, Blood Agar (OxoidTM, CM0055) and MacConkey Agar (OxoidTM, CM0007) for growing selectively. Finally, those were subject to different biochemical tests for identification. The biochemical tests were Catalase test, Oxidase test, Coagulase test, Motility test, Indole test, MRVP, Citrate utilization, and Urease test. All these biochemical tests were done according to the standard methods. After all the biochemical tests, results were observed and interpreted. The workflow has been summarized in Figure-1.

\section{RESULTS}

The results of both raw and commercial honeys are described in Table-1 and Table-2. Also, the number of identified species in each sample source and prevalence of different bacterial species are represented graphically in Figure-2 (a), (b) \& (c).

Table.1: Bacteria identified in raw honeys

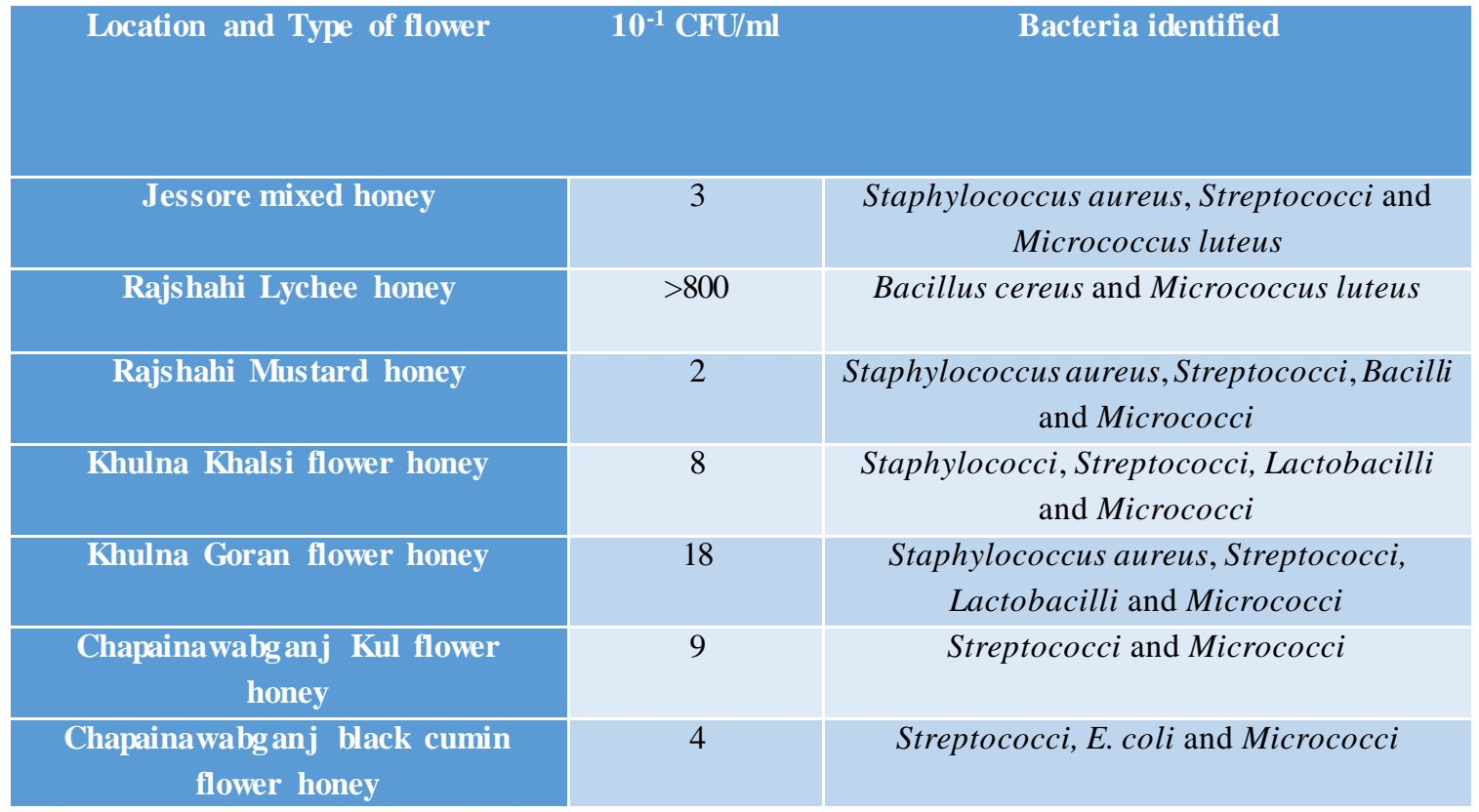


Table.2: Bacteria identified in commercial honeys

\begin{tabular}{|c|c|c|}
\hline Product name & $10^{-1} \mathrm{CFU} / \mathrm{ml}$ & Bacteria identified \\
\hline C1 & 5 & Staphylococcus aureus, Streptococci, Bacilli and Micrococci \\
\hline $\mathbf{C 2}$ & 100 & Staphylococcus aureus, Streptococci and Micrococci \\
\hline $\mathbf{C 3}$ & 4 & Klebsiella, Staphylococcus aureus, Streptococci and Micrococci \\
\hline C4 & 79 & Staphylococcus aureus, Streptococci and Micrococci \\
\hline C5 & 17 & Staphylococcus aureus, Streptococci and Micrococci \\
\hline C6 & $>200$ & Staphylococcus aureus, Streptococci and Micrococci \\
\hline
\end{tabular}

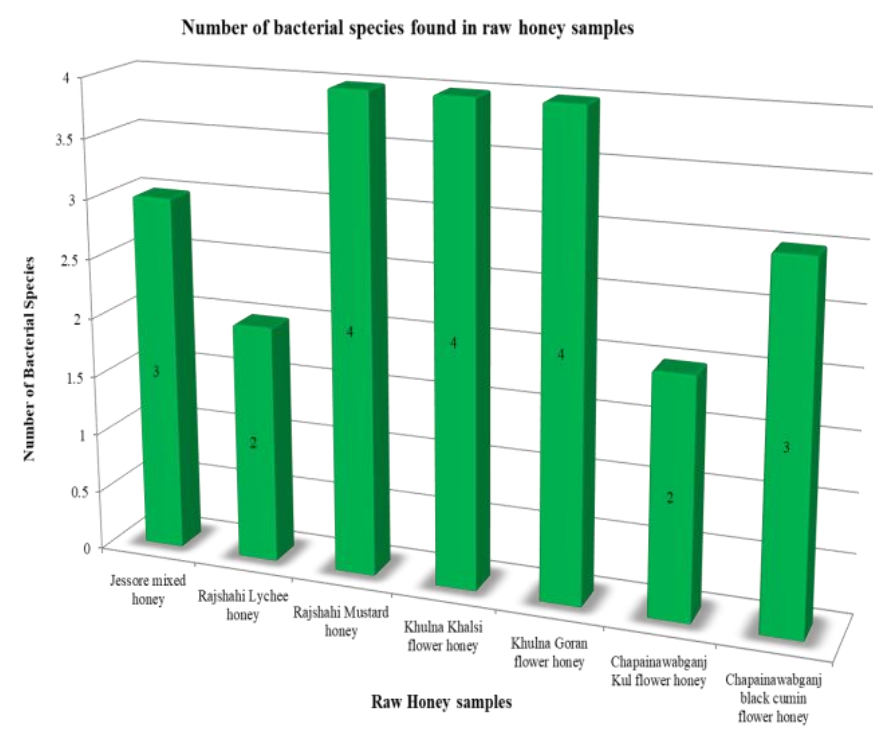

(a)

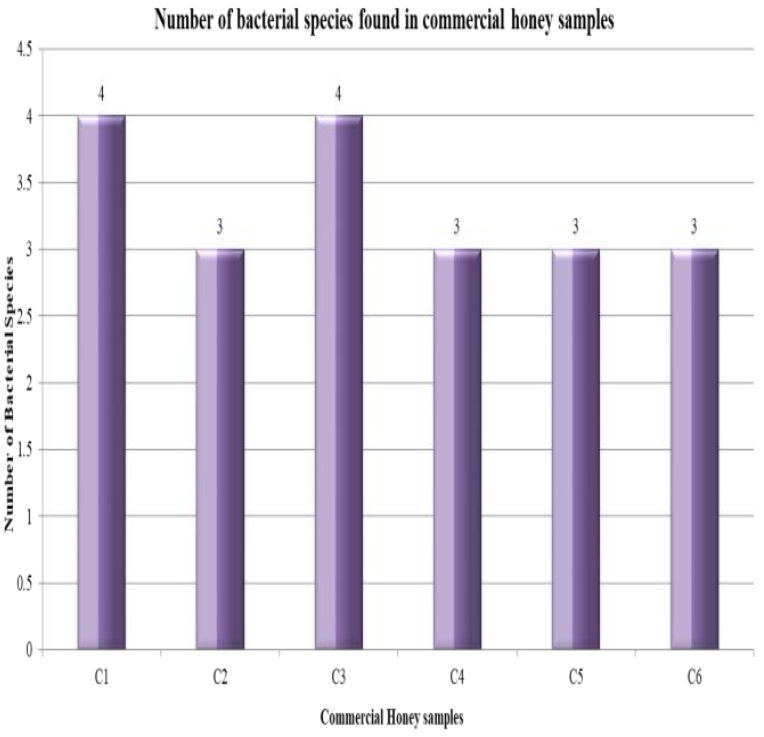

(b)

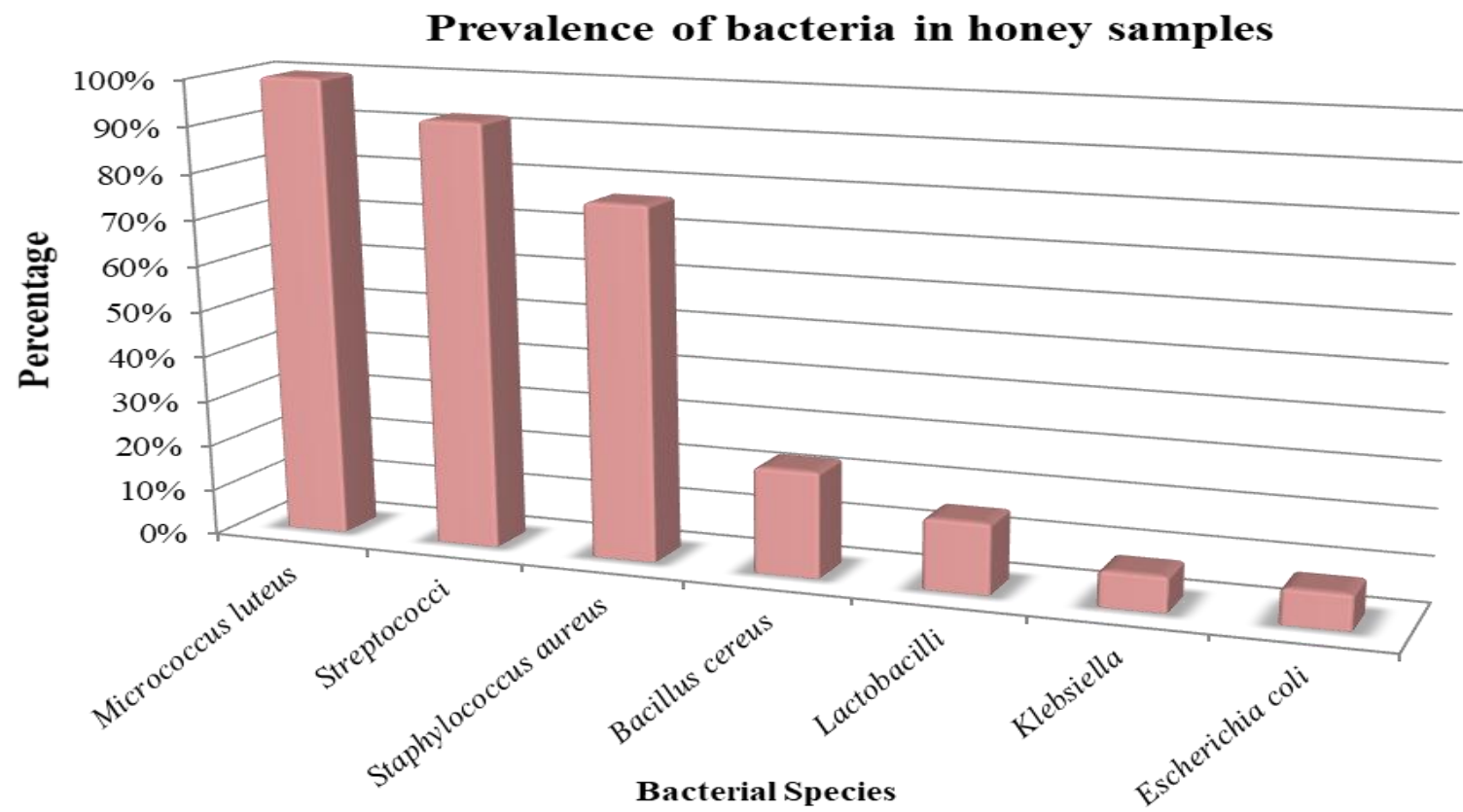

(c)

Fig.2:(a)Number of bacterial species found in raw honeys. (b) Number of bacterial species found in commercial honeys.(c) Prevalence of different bacterial species in percentage (\%). 


\section{DISCUSSION}

Most of the studies conducted on honey had been focused on the antibacterial properties of honey. However, in two of the similar studies, the presence of Bacilli, Staphylococcus aureus, Klebsiella and E.coli were determined. But there was also the presence of Pseudomonasaeruginosa, Shigella spp. and Enterobacter[14,15].

Herein we showed, the bacteria isolated and identified in both raw and commercial honey; which wereMicrococcus luteus(100\%), Streptococcus (92\%), Staphylococcus aureus (77\%), Bacillus (23\%), Lactobacillus (15\%), Klebsiella (8\%) and Escherichia coli (8\%). It can be noticed that there are similarities between the species of bacteria which were found in all of the thirteen honey samples. The variety of species were found to be high in local raw honey samples rather than in commercial honeys. But the number of bacteria were found to be significantly high in the commercial honeys. Although the bacterial content of two of the commercial honeys were high in amount, as these honeys were found to be highly diluted.In a similar study conducted in Pakistan, it was shown that the quantity of colony forming unit was high; as found in this study[16]. In another research conducted by Amy K. Breslin et al. (2011), the local honeys were found to be more contaminated than the commercial honeys [17].Similarly, Snowdon and Cliver (1996) showed that different microbial species in honey may reach a concentration of some thousands colony forming unit (CFU) per gram [11]. It can be seen that the findings in these studies conducted in other countries support the existence of microorganisms in honey samples as done in our study.But surprisingly in a study conducted by Peter B. Olaitan et al. (2007), Yeast, Streptomyces, Mould, Actinomycetes were detected unlike the other researchers [5]. So if further researches are done with broader sample sources, there are possibilities that more different species might be found to be present in honeys. It is to be noted that 16s RNA sequencing could be done in future researches to identify the bacteria specifically.

The bacteria that were identified in these honeys have numerous good effects on human health. It was found that Bacillus species produces bacitracin, a peptide antibiotic that is effective against other gram-positive bacteria [18]. This bacitracin functions by inhibiting the cell wall. Bacillus also produces some other important antibiotics such as subtilin, surfactin and mycobacillin [18-20]. Micrococcus luteus produces an antibiotic called neoberninamycin which is effective against gram-positive and anaerobic bacteria [21].A species of Streptococcus calledStreptococcus thermophilus was found to be beneficial for the patients with lactose intolerance disorder as this species produces the enzyme lactase[22]. This bacterium also produces antibiotic-like substances and bactericidal proteins called bacteriocins [22]. Also Staphylococcus aureus was found to show inhibitory effect on autoimmune inflammation of the central nervous system and prevent the development of clinical experimental autoimmune encephalomyelitis [23].

\section{CONCLUSION}

Though honey is widely used as a sweetener andit has good effects on health, it was necessary to determine the microbial quality of Bangladeshi honey. From this study it was found that commercial honeys and natural raw honey from flowers in different areas of Bangladesh contains various bacteria.These bacteria are known to produce some secondary metabolites which can be used as bioactive agents in ailment of various diseases.

\section{ACKNOWLEDGMENT}

The authors are thankful to the Department of Biochemistry and Microbiology, North South University for the wet lab support. The authors would like to thank Dr. Chaman Ara Keya for continuous motivation. Also thanks to Md. Asikul Wadud. No financial support was received from any sources for conducting this project.

\section{REFERENCES}

[1] Alberoni, D., Gaggìa, F., Baffoni, L., \& Di Gioia, D. (2016). Beneficial microorganisms for honey bees: problems and progresses. Applied Microbiology and Biotechnology. https://doi.org/10.1007/s00253-0167870-4

[2] Amin, A., Khan, M. A., Ehsanullah, M., Haroon, U., Azam, S. M. F., \& Hameed, A. (2012). Production of peptide antibiotics by Bacillus sp. GU 057 indigenously isolated from saline soil. Brazilian Journal of Microbiology: [Publication of the Brazilian Society for Microbiology], 43(4), 1340-6. https://doi.org/10.1590/S1517-838220120004000015

[3] Babendreier, D., Joller, D., Romeis, J., Bigler, F., \& Widmer, F. (2007). Bacterial community structures in honeybee intestines and their response to two insecticidal proteins. FEMS Microbiology Ecology, 59(3), 600-610. https://doi.org/10.1111/j.15746941.2006.00249.x

[4] Biskupiak, J. E., Meyers, E., Gillum, A. M., Dean, L., Trejo, W. H., \& Kirsch, D. R. (1988). Neoberninamycin, a new antibiotic produced by 
Micrococcus luteus. The Journal of Antibiotics, 41(5),

684-7. Retrieved from http://www.ncbi.nlm.nih.gov/pubmed/3384754

[5] Breslin, A. K., Meyer, B. M., Dria, W. S., Vanata, D. F., \& Greene, A. V. (2011). Enumeration and Identification of Bacterial Contaminants in Commercial and Locally Produced Honey. BIOS, 82(4), 103-111. https://doi.org/10.1893/011.082.0401

[6] Chowdhury, A., Islam, S., \& Chowdhury, R. (2018). Antibacterial Activity of Bangladeshi Raw and Commercial Honey Against Staphylococcus aureus, 4(1), $1-5$. https://doi.org/10.19080/NAPDD.2018.04.555626.

[7] French, V. M., Cooper, R. A., \& Molan, P. C. (2005). The antibacterial activity of honey against coagulasenegative staphylococci. The Journal of Antimicrobial Chemotherapy, 56(1), 228-31. https://doi.org/10.1093/jac/dki193

[8] Gilliam, M. (1997). Identification and roles of nonpathogenic microflora associated with honey bees. FEMS Microbiology Letters. https://doi.org/10.1016/S0378-1097(97)00337-6

[9] Gilliam, M., \& Prest, D. B. (1987). Microbiology of feces of the larval honey bee, Apis mellifera. Journal of Invertebrate Pathology, 49(1), 70-75. https://doi.org/10.1016/0022-2011(87)90127-3

[10] Gilliam, M., Prest, D. B., \& Lorenz, B. J. (1989). Microbiology of pollen and bee bread : taxonomy and enzymology of molds. Apidologie, 20(1), 53-68. https://doi.org/10.1051/apido:19890106

[11] Iqbal, M. N., Anjum, A. A., Ali, M. A., Hussain, F., Ali, S., Muhammad, A., ... Shabbir, A. (2015). Assessment of Microbial Load of Un-pasteurized Fruit Juices and in vitro Antibacterial Potential of Honey Against Bacterial Isolates. The Open Microbiology Journal, 9 , 26-32. https://doi.org/10.2174/1874285801509010026

[12] Kumar, P., Kretzschmar, B., Herold, S., Nau, R., Kreutzfeldt, M., Schütze, S., ... Hein, K. (2015). Beneficial effect of chronic Staphylococcus aureus infection in a model of multiple sclerosis is mediated through the secretion of extracellular adherence protein. Journal of Neuroinflammation, 12, 22. https://doi.org/10.1186/s 12974-015-0241-8

[13] Mandal, M. D., \& Mandal, S. (2011). Honey: its medicinal property and antibacterial activity. Asian Pacific Journal of Tropical Biomedicine, 1(2), 154 60. https://doi.org/10.1016/S2221-1691(11)60016-6

[14] Mannanov， R. N., \& Sattarova, R. K. (2001).
Antibiotics produced by Bacillus bacteria. Chem. Nat., Comp., 37(2), 117-123.

[15] Nakano, M. M., \& Zuber, P. (1990). Molecular biology of antibiotic production in bacillus. Critical Reviews in Biotechnology, 10(3), 223-240. https://doi.org/10.3109/07388559009038209

[16] Naseer, S., Khan, S. A., \& Azim, M. K. (2015). Identification of cultivable bacteria from natural honey of different botanical origin. The Pakistan Journal of Biochemistry and Molecular Biology, 48(2), 53-56. Retrieved from http://www.pjbmb.org.pk/images/PJBMBArchive/201 5/PJBMB_48_2_Jun_2015/5.pdf

[17] Olaitan, P. B., Adeleke, O. E., \& Ola, I. O. (2007). Honey: a reservoir for microorganisms and an inhibitory agent for microbes. African Health Sciences, $\quad 7(3), \quad 159-65$. https://doi.org/10.5555/afhs.2007.7.3.159

[18] Sackett, W. G. (1919). Honey As a Carrier of Intestinal Diseases. The Agricultural Experiment Station of the Colorado Agricultural College, 1-18.

[19] Shahedur, R., Faizus, S., \& Asif, I. (2011). Antibacterial efficacy of raw and commercially available honey. African Journal of Biotechnology, 10(54),

11269-11272. https://doi.org/10.5897/AJB10.1954

[20] Sharma, R., Bhaskar, B., S. Sanodiya, B., S. Thakur, G., Jaiswal, P., Yadav, N., ... S Bisen, P. (2014). Probiotic Efficacy and Potential of Streptococcus thermophilus modulating human health: A synoptic review. IOSR Journal of Pharmacy and Biological Sciences, 9(3), 52-58. https://doi.org/10.9790/300809325258

[21] WANG, M., ZHAO, W.-Z., XU, H., WANG, Z.-W., \& HE, S.-Y. (2015). Bacillus in the guts of honey bees (Apis mellifera; Hymenoptera: Apidae) mediate changes in amylase values. European Journal of Entomology. https://doi.org/10.14411/eje.2015.095

[22] Wang, R., Starkey, M., Hazan, R., \& Rahme, L. G. (2012). Honey's Ability to Counter Bacterial Infections Arises from Both Bactericidal Compounds and QS Inhibition. Frontiers in Microbiology, 3, 144. https://doi.org/10.3389/fmicb.2012.00144

[23] White, P. B. (1921). The normal bacterial flora of the bee. The Journal of Pathology and Bacteriology, 24(1), 64-78. https://doi.org/10.1002/path.1700240106 